\title{
Play, Imagination, and Creativity: A Brief Literature Review
}

\author{
Kuan Chen Tsai ${ }^{1}$ \\ ${ }^{1}$ Dreeben School of Education, University of the Incarnate Word, San Antonio, USA \\ Correspondence: Kuan Chen Tsai, Dreeben School of Education, University of the Incarnate Word, San Antonio, \\ Texas, 78209, USA. Tel: 1-210-505-5155. E-mail: ktsai@student.uiwtx.edu
}

Received: July 20, 2012

Accepted: August 3, 2012

Online Published: August 27, 2012

doi:10.5539/jel.v1n2p15

URL: http://dx.doi.org/10.5539/jel.v1n2p15

\begin{abstract}
What the ultimate goal for education is to help students develop their capabilities and in turn to maximize their potentials into practical uses in everyday life. In fact, teachers are critical resources at their disposal to facilitate maximum students learning experience and to release students' potentials in classrooms. It is believed that creativity is an important capacity for students to possess in order to face this fast-changing world. The purpose of current study is to review related literature on play, imagination, and creativity. By doing so, it is hoped to provide some useful insights for educators to bring those concepts into classrooms in terms of promoting creativity. Finally, several creativity strategies for facilitating creativity are discussed. The overall results of the literature review suggest that educators should bring play and imagination in their classrooms in order to encourage creativity.
\end{abstract}

Keywords: play, imagination, creativity

\section{Introduction}

"Fundamental to living in the conceptual age will be the use of creativity" (Warner \& Myers, 2009, p. 29). Creativity has becoming a topic of ever-increasing interest to educational settings (Clegg, 2008; Feldman \& Benjamin, 2006). Teachers are imperative resource at their disposal to facilitate maximum students learning experience and to release students' potentials in classrooms. Like it or not, teachers serve as the metronome in the classrooms (Creme, 2003; Gibson, 2010). What the ultimate goal for education is to help students develop their capabilities and in turn to maximize their potentials into practical uses in everyday life.

The purpose of current study is to review related literature on play, imagination, and creativity. By doing so, it is hoped to provide some useful insights for educators to bring those concepts into classrooms in terms of promoting creativity. First, the definition of creativity is reviewed. Then, the relationship between creativity and imagination is submitted. Moreover, the concept and related empirical studies of play and creativity are presented. Finally, several creativity strategies for facilitating creativity are discussed.

\section{Characteristics of Creativity}

There is a clear consensus in the field of creativity that differentiates between the creative product and the creative process (Hennessey, 2003; Lubart, 1990; Runco, 2006). A creative product is often judged by its novelty (originality) and utility (usefulness) (Barron, 1955; MacKinnon, 1962). Wallas (1926) illustrated four stages of the creative process: preparation, incubation, illumination, and verification and this notion were extended to the implementation of Creative Problem Solving Model (Meadow \& Parnes, 1959; Meadow, Parnes, \& Reese, 1959). The creative process refers to the involvement of a creative action with a transformation phase that develops toward an implementation phase of creative production (Taylor, 1974), which includes cognitive, affective, and personality processes (Hennessey \& Amabile, 2010; Russ, 2003; Saracho, 1992). Finally, Torrance and Myers (1970) defined creative learning process as,

One of becoming sensitive to aware of problems, deficiencies, gaps in knowledge, missing elements, disharmonies, and so on; bring together available information; defining the difficulty or identifying the missing element; searching for solutions, making guesses, or formulating hypotheses about the deficiencies; testing and retesting these hypotheses, and modifying and retesting them; perfecting them; and finally communicating the results. (p. 22)

\section{Creativity and Imagination}

Vygotsky (1930/2004) theorized the relationship between creativity and imagination. He denoted that the 
imagination serves as an imperative impetus of all human creative activity. The fact that this human creative behavior "makes the human being a creature oriented toward the future, creating the future and thus altering his own present" (p. 9). As a result, Vygotsky (1930/2004) claimed that the operation of imagination is "a function essential to life" (p. 13). In Vygotsky's view, the most principle that formulates the operation of the imagination is contingent on the richness and wideness an individual's experience because "imagination always builds using materials supplied by reality" (p. 14). Thus, he argued that a child has less rich imagination than an adult as expected. Additionally, the interplay between the affective (emotion) factor and imagination, which he called the "emotional reality of the imagination" (p. 19), is also play an important role to shape the imagination. The imagination in fact involves feelings that manifest a person truly experiences. However, the process of imagination is not only guided by personal feelings. Vygotsky pointed out the importance of the context in this process and stated "every inventor, even a genius, is also a product of his time and his environment... Creation is a historical, cumulative process where every succeeding manifestation was determined by the preceding one" (p. 30).

Vygotsky (1931/1991) proposed that "imagination in adolescence is, from the developmental point of view, the successor of children's play" (p. 77). However, Vygotsky (1930/2004, 1931/1991) differentiated the functioning of creative imagination between adults and children. The key difference is rooted in the level of maturity. He depicted that a child's experience is simpler, more elementary, and poorer; on the other hand, an adult's experience is subtler, more complex, and diverse. Further, owing to developmental issue, the fact that "the convergence of intellect and imagination is a distinctive characteristic of development in adolescence" (Vygotsky, 1931/1991, p. 83) contributes to that adults have more abstract and creative imagination and fantasy than children do. Consequentially, the imagination is fully mature only in the developmental stage of adulthood. In addition, during the transition from childhood to adulthood, two types of imagination gradually clearly exhibit at the adolescent stage. First is plastic (external) imagination that utilizes external materials to construct the products. The second one is emotional (internal) imagination that builds the rules of the construction.

Finally, Smolucha and Smolucha (1986) summarized four key components of Vygotsky's theory of creative imagination:

1) Imagination is the internalization of children's play.

2) Imagination is a higher mental function of as such is a consciously directed thought process.

3) Creative thinking involves the collaboration of imagination and thinking in concepts, which occurs first in adolescence but mature in adulthood.

4) Both artistic and scientific creativity require the collaboration of imagination and thinking in concepts (p. 4).

\section{Creativity and Play Behavior}

In the psychology literature, divergent thinking is closely married to creativity (Guilford, 195; Torrance, 1988; Williams, 2004). Indeed, divergent thinking is viewed as one major element of the cognitive process in creativity (Dirkes, 1978; Guilford, 1956; Runco, 2004). Divergent thinking is dependent on fluidity of thinking and free association, which is independent of intelligence (Sternberg \& Lubart, 1995; Sternberg, 2006). Affective processes also account for the creative processes. Csikszentmihalyi (1996) identified an individual will have a flow experience while engaging in creative activity. Amabile (1996) has uncovered the importance of intrinsic motivation in creativity, which Torrance (2004) called "a labor of love."

Play provides an arena for creative activities and processes (Hennessey \& Amabile, 1987; Saracho, 2002). Some observations of creative adults uncovered that their work processes stem from some aspects of child's play (Root-Bernstein \& Root-Bernstein, 2006). Theoretically, pretend play and creativity are interconnected under the structure of cognitive and affective processes (Russ, 1998, 2003). To some extent, play and creativity may share the same prime configuration (Saracho, 1992). Vygotsky (1932/1987) delineated a developmental view of adolescent creativity that underlines the interactions between imagination and reasoning which lead to more mature and productive forms of creative thinking in adulthood. The transition from imagination and fantasy of childhood to adolescence, according to Vygotsky, is changed into content and nature. With the increase of social experiences and maturation of both emotion and intellect, adults enjoy creativity with depth and complexity.

Based on Russ's (1998) literature review on creativity and play, she proposed a model that involves the cognitive and affective processes in creativity and also identified several fruitful connections between two variables: divergent thinking, transformation abilities, expression of emotion, and expression of affect-laden fantasy (p. 476). A number of studies have demonstrated the mechanism that pretend play facilitates creativity through cognitive and affective processes in children (Dansky \& Silverman, 1973; Howard-Jones, Taylor, \& Sutton, 2002; Moore \& Russ, 2008; Russ \& Schafer, 2006; Saracho, 1992). Their major findings lend support to empirical links between 
play and divergent thinking. From the affective perspective, their study exhibits the utilization of fantasy and imagination in early pretend play, which in turn develops a broad repertoire of free flow of associations. The interplay between play and creativity is grounded in this broadened associative network that is beneficial for developing divergent thinking and creative problem solving (Dansky, 1980; Lieberman, 1965; Russ \& Kaugars, 2000).

\section{Bring Play Mood and Imagination in Classrooms}

Torrance (1972) found the most effective training for stimulating creativity involves both cognitive and affective attributes. Following this line, it is believed that the mood of play could have its face value that facilitates creativity. Craft (2003) mentioned "play is necessary to creativity, not all play is creative" (p. 150). As a result, when educators attempt to utilize play strategies in teaching, they need to consider the purpose of those activities. Most important, how those play activities tap into creativity.

With regard to implementation of creative-thinking techniques in classrooms, Mycoted, a British company, inventories useful 183 creative-thinking methods on its web site (http://www.mycoted.com/Category:Creativity_Techniques). In the similar thread, CREAX provides 837 of websites on creativity to learners. In addition, Houston (2007) has outlined a number of lessen plans that target to stimulate creative thinking (www.hallhouston.com). After reviewing numerous creativity-increasing tools, Lau, $\mathrm{Ng}$, and Lee (2009) recognized five main categories: (a) Identifying and mapping attributes (e.g., mapping notes or critical analysis); (b) Making possibilities; (c) Changing and shifting perspectives (e.g., divergent thinking); (d) Making associations and analogical thinking; (e) Probing emotion and the subconscious (p. 72).

Taken together, the main purpose of those activities is to "play" your ideas and explore alternative pathways to solve the problems. Through those exercises, teachers should also cultivate a "play" environment that encourages students using their imagination and creativity to view things from different perspectives. In fact, the capacity to perceiving information from different lens and reconstructing the existing knowledge is imperative for those creative geniuses to accomplish major achievements to their fields (Mumford, 1984). Consequently, this play mood of toying with ideas for the sake of shifting paradigm should be promoted in educational settings. Above all, this play mood could energize students' learning experience and interest, which in turn facilitate creative development and meaningful learning.

With the overemphasis of accountability and standardized tests in the current U.S. education milieu, students, teachers, parents, and schools feel overwhelming pressure and stress. This phenomenon also triggers the deviation from initial goal of education "teaching for education" to "teaching for tests." Therefore, it is imperative for American educators to rethink the education system and to refocus the purpose of education (Baer \& Garrett, 2010; Beghetto \& Kaufman, 2010). On the other hand, Great Britain has recognized the power of creative thinking and critical thinking, especially the necessary skills for twenty first century. For example, Qualifications and Curriculum Authority/Department for Education and Employment (QCADEE, 2000) from U.K. suggested that through well-planned play, students will not only learn with enjoyment and problem solving but also develop creative thinking and imaginative thinking. As a result, QCADEE (1999) has underscored the importance of curriculum and argued that the curriculum should enable pupils to "think creatively and critically, to solve problems and to make a difference for the better. It should give them the opportunity to become creative, innovative, enterprising and capable of leadership to equip them for their future lives as workers and citizens" (p. 11).

In addition to the design of curriculum that should include the elements of play, imagination, and creativity, Myers and Torrance (1961) recommended five principles for rewarding creative thinking in children: (1) treat questions with respect, (2) treat imaginative idea with respect, (3) value students' ideas, (4) encourage practice-leaning without the threat of evaluation, and (5) tie in evaluation with causes and consequences. In the same vein, Hennessey and Amabile (1987) provided some suggestions for educators to stimulate creative behaviors in the classrooms: (1) children will be most creative when they enjoy the task; (2) avoid using tangible rewards; (3) avoid setting up competitive situations; (4) downplay the evaluation of children's work; (5) encourage children to monitor their own work; (6) make intrinsic motivation a conscious factor of your discussions with children; (7) help children build their self-esteem and focus on and appreciate their own unique talents and strengths; (8) give ample opportunities for free play with various materials; (9) show children that you value creativity; (10) show your students that you are an intrinsically motivated adult who enjoys thinking creatively (p. 25).

In closing, in order to facilitate the best opportunity for effective creative development, QCADEE (2000) provided some suggestions for practitioners: (1) a stimulating environment in which creativity, originality and expressiveness are valued; (2) sufficient time for learners to explore; (3) a wide range of activities that learners can 
respond to by using many sense; (4) opportunities for learners to express their ideas through a wide range of types of representation; (5) opportunities to work alongside creative people (p. 116). To sum up, teachers, in fact, stand in a unique position in fostering creativity in the classroom. They should not only encourage students to express their creativity, but also utilize different materials and teaching approaches to inspire students' imagination and think outside of the box. Most important, teachers should cultivate a pleasing and playful environment without pressure for students to explore their wonderlands.

\section{Conclusions}

Magno (2009) stated "creativity is a product of an executed imagination" (p. 10). Anderson (1994) identified that "play depends on two rudimentary ingredients: safety and stimulation" (p. 81). On the one hand, play involves uncertainty; thus teachers should recognize this risk-free ramification. On the other hand, play involves the use of personal energy and strategy. Adequate stimuli are necessary to make that happen.

Due to "the ability to think imaginatively in a free-association style and to be open to thinking about affect-laden material being related processes" (Suler, 1980, p.770), it is hypothesized that the perspective of affect in play coupled with imagination will maximize creative potential of individual. Therefore, in order to nourish creativity in learners, it is suggested teachers should bring play mood into classrooms, provide appropriate stimulation, and cultivate a risk-free learning environment. By doing so, it is hoped to unleash creative potential of individual in the long run.

\section{References}

Amabile, T. M. (1996). Creativity in context: Update to the social psychology of creativity. Boulder, CO: Westview Press.

Anderson, J. V. (1994). Creativity and play: A systematic approach to managing innovation. Business Horizons, 37, $80-85$.

Baer, J., \& Garrett, T. (2010). Teaching for creativity in an era of content standards and accountability. In R. A. Beghetto \& J. C. Kaufman (Eds.), Nurturing creativity in the classroom (pp. 6-23). New York: Cambridge University Press.

Barron, F. (1955). The disposition toward originality. Journal of Abnormal Psychology, 51, 478-485.

Beghetto, R. A., \& Kaufman, J. C. (2010). Broadening conceptions of creativity in the classroom. In R. A. Beghetto \& J. C. Kaufman (Eds.), Nurturing creativity in the classroom (pp. 191-205). New York: Cambridge University Press.

Clegg, P. (2008). Creativity and critical thinking in the globalised university. Innovations in Education \& Teaching International, 45, 219-226. http://dx.doi.org/10.1080/14703290802175982

Craft, A. (2003). Creative thinking in the early years of education. Early Years: Journal of International Research \& Development, 23, 143-154.

Creme, P. (2003). Why can't we allow students to be more creative? Teaching in Higher Education, 8, 273-277.

Csikszentmihalyi, M. (1996). Creativity: Flow and the psychology of discovery and invention. New York: HarperCollins.

Dansky, J. L. (1980). Make-believe: A mediator of the relationship between play and associative fluency. Child Development, 51, 576-579.

Dansky, J. L., \& Silverman, I. W. (1973). Effects of play on associative fluency in preschool-aged children. Developmental Psychology, 9, 38-43.

Dirkes, M. (1978). The role of divergent production in the learning process. American Psychologist, 33, 815-820. http://dx.doi.org/10.1037/0003-066X.33.9.815

Feldman, D., \& Benjamin, A. C. (2006). Creativity and education: An American retrospective. Cambridge Journal of Education, 36, 319-336.

Gibson, R. (2010). The "art” of creative teaching: Implications for higher education. Teaching in Higher Education, 15, 607-613. http://dx.doi.org/10.1080/13562517.2010.493349

Guilford, J. P. (1950). Creativity. American Psychologist, 5, 444-454. http://dx.doi.org/10.1037/h0063487

Guilford, J. P. (1956). The structure of intellect. Psychological Bulletin, 53, 267-293.

Hennessey, B. A. (2003). The social psychology of creativity. Scandinavian Journal of Educational Research, 47, 
253-271.

Hennessey, B. A., \& Amabile, T. M. (1987). Creativity and learning: What research says to the teacher. West Haven, CT; National Education Association.

Hennessey, B. A., \& Amabile, T. M. (2010). Creativity. Annual Review of Psychology, 61, 569-598.

Houston, H. (2007). The creative classroom: Teaching language outside the box. Auburn, WA: Lynax.

Howard-Jones, P., Taylor, J., \& Sutton, L. (2002). The effect of play on the creativity of young children during subsequent activity. Early Child Development \& Care, 172, 323-328.

Lau, K. W., Ng, M. F., \& Lee, P. Y. (2009). Rethinking the creativity training in design education: A study of creative thinking tools for facilitating creativity development of design students. Art, Design \& Communication in Higher Education, 8, 71-84. http://dx.doi.org/10.1386/adch.8.1.71_1

Lieberman, J. N. (1965). Playfulness and divergent thinking: An investigation of their relationship at the kindergarten level. Journal of Genetic Psychology, 107, 219-224.

Lubart, T. I. (1990). Creativity and cross-cultural variation. International Journal of Psychology, 25, 39-59.

MacKinnon, D. W. (1962). The nature and nurture of creative talent. American Psychologist, 17, 484-495.

Magno, C. (2009). Explaining the creative mind. International Journal of Research \& Review, 3, 10-19.

Meadow, A., \& Parnes, S. J. (1959). Evaluation of training in creative problem solving. Journal of Applied Psychology, 43, 189-194. http://dx.doi.org/10.1037/h0046040

Meadow, A., Parnes, S. J., \& Reese, H. (1959). Influence of brainstorming instructions and problem sequence on a creative problem solving test. Journal of Applied Psychology, 43, 413-416. http://dx.doi.org/10.1037/h0043917

Moore, M., \& Russ, S. W. (2008). Follow-up of a pretend play intervention: Effects on play, creativity, and emotional processes in children. Creativity Research Journal, 2, 427-436. http://dx.doi.org/10.1080/10400410802391892

Mumford, M. D. (1984). Age and outstanding occupational achievement: Lehman revisited. Journal of Vocational Behavior, 25, 225-244.

Myers, R. E., \& Torrance, E. P. (1961). Can teachers encourage creative thinking? Educational Leadership, 19, 156-159.

Qualifications and Curriculum Authority/Department for Education and Employment. (1999). The national curriculum handbook for primary teachers in England. London, UK: DfEE/QCA.

Qualifications and Curriculum Authority/Department for Education and Employment. (2000). Curriculum guidance for the foundation stage. London, UK: DfEE/QCA.

Root-Bernstein, M., \& Root-Bernstein, R. (2006). Imaginary worldplay in childhood and maturity and its impact on adult creativity. Creativity Research Journal, 18, 405-425. http://dx.doi.org/10.1207/s15326934crj1804_1

Runco, M. A. (2004). Creativity. Annual Review of Psychology, 55, 657-687. http://dx.doi.org/10.1146/annurev.psych.55.090902.141502

Runco, M. A. (2006). Reasoning and personal creativity. In J. C. Kaufman \& J. Baer (Eds.), Creativity and reason in cognitive development (pp. 99-116). New York: Cambridge University Press.

Russ, S. W. (1988). Primary process thinking, divergent thinking, and coping in children. Journal of Personality Assessment, 52, 539-548.

Russ, S. W. (2003). Play and creativity: Developmental issues. Scandinavian Journal of Educational Research, 47, 291-303.

Russ, S. W., \& Kaugars, A. (2000). Emotion in children's play and creative problem solving. Creativity Research Journal, 13, 211-219.

Russ, S. W., \& Schafer, E. D. (2006). Affect in fantasy play, emotion in memories, and divergent thinking. Creativity Research Journal, 18, 347-354. http://dx.doi.org/10.1207/s15326934crj1803_9

Saracho, O. N. (1992). Preschool children's cognitive style and play: Implications for creativity. Creativity Research Journal, 5, 35-47.

Saracho, O. N. (2002). Young children's creativity and pretend play. Early Child Development \& Care, 172, 
431-438.

Smolucha, L., \& Smolucha, F. C. (1986, August). L.S. Vygotsky's theory of creative imagination. Paper presented at 94th Annual Convention of the American psychological Association, Washington, DC.

Sternberg, R. J. (2006). The nature of creativity. Creativity Research Journal, 18, 87-98. http://dx.doi.org/10.1207/s15326934crj1801_10

Sternberg, R. J., \& Lubart, T. I. (1995). Defying the crowd: Cultivating creativity in a culture of confomity. New York: The Free Press.

Suler, J. R. (1980). Primary process thinking and creativity. Psychological Bulletin, 88, 144-165.

Taylor, I. A. (1974). Developing creativity in gifted young adults. Education, 94, 266-268.

Torrance, E. P. (1972). Predictive validity of the Torrance Tests of Creative Thinking. The Journal of creative behavior, 6, 236-262.

Torrance, E. P. (1988). The nature of creativity as manifest in its test. In R. J. Sternberg (Ed.), The nature of creativity: Contemporary psychology perspectives (pp. 43-75). New York: Cambridge University Press.

Torrance, E. P. (2004). Great expectations: Creative achievements of the sociometric stars in a 30-year study. Journal of Secondary Gifted Education, 1, 5-13.

Torrance, E. P., \& Myers, R. E. (1970). Creative learning and teaching. New York, NY: Dodd, Mead \& Company.

Vygotsky, L. S. (1930/2004). Imagination and creativity in childhood. Journal of Russian and East European Psychology, 42, 7-97.

Vygotsky, L. S. (1931/1991). Imagination and creativity in the adolescent. Soviet Psychology, 29, 73-88.

Wallas, G. (1926). The art of thought. New York: Harcourt Brace Jovanovich.

Warner, S. A., \& Myers, K. L. (2009). The creative classroom: The role of space and place toward facilitating creativity. Technology Teacher, 69, 28-34.

Williams, S. D. (2004). Personality, attitude, and leader influences on divergent thinking and creativity in organizations. European Journal of Innovation Management, 7, 187-204. 